3-1976

\title{
Crime, Punishment and Personality: Examination of Deterrence Question
}

\author{
William C. Bailey \\ Cleveland State University, w.bailey@csuohio.edu \\ Ruth P. Lott \\ Cuyohoga Community College
}

Follow this and additional works at: https://engagedscholarship.csuohio.edu/clsoc_crim_facpub

Part of the Criminology Commons, and the Social Psychology and Interaction Commons How does access to this work benefit you? Let us know!

Publisher's Statement

(c) 1976 University of Illinois Press

\section{Original Citation}

Bailey, W. C., \& Lott, R. P. (1976). Crime, Punishment and Personality: An Examination of the Deterrence Question. Journal Of Criminal Law \& Criminology, 67(1), 99-109.

\section{Repository Citation}

Bailey, William C. and Lott, Ruth P., "Crime, Punishment and Personality: Examination of Deterrence Question" (1976). Sociology \& Criminology Faculty Publications. 72.

https://engagedscholarship.csuohio.edu/clsoc_crim_facpub/72

This Article is brought to you for free and open access by the Sociology \& Criminology Department at EngagedScholarship@CSU. It has been accepted for inclusion in Sociology \& Criminology Faculty Publications by an authorized administrator of EngagedScholarship@CSU. For more information, please contact library.es@csuohio.edu. 


\title{
CRIME, PUNISHMENT AND PERSONALITY: AN EXAMINATION OF THE DETERRENCE QUESTION
}

\author{
William C. Bailey, Cleveland State University \\ Ruth P. Lott, Cuyohoga Community College
}

This article was originally published in:

Bailey, William C. and Ruth P. Lott (1976).Crime Punishment and Personality: An Examination of the Deterrence Question. The Journal of Criminal Law and Criminology, 67(1), 99-109.

Post-print standardized by MSL Academic Endeavors, the imprint of the Michael Schwartz Library at Cleveland State University, 2013

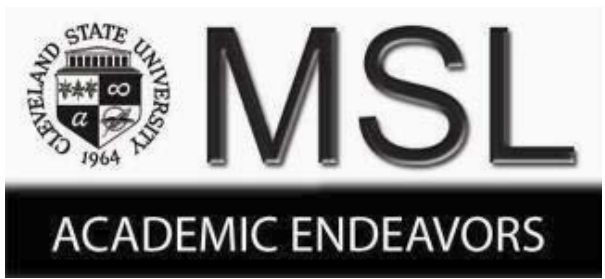




\title{
CRIME, PUNISHMENT AND PERSONALITY: AN EXAMINATION OF THE DETERRENCE QUESTION
}

\author{
WILLIAM C. BAILEY* AND RUTH P. LOTT**
}

While the presumed deterrent effect of punishment provides the cornerstone of our criminal justice system, it would be a mistake to assume that deterrence is well established in theory and research. As Gibbs, ${ }^{1}$ Ball, ${ }^{2}$ Puttkammer ${ }^{3}$ and others have pointed out, despite the length and intensity of the deterrence controversy, much of the debate has been of a moral and ideological nature with few of the protagonists providing any systematic evidence in support of their positions. Moreover, Tittle ${ }^{4}$ concludes that much of the evidence cited is inadequate or inappropriate to the question at issue. This is a regrettable situation for much of the deterrence question is clearly amenable to empirical investigations.

Until recent years, most deterrence investigations have focused primarily upon homicide and the death penalty. These investigations have led most investigators to accept what Sellin has termed the inevitable conclusion: "the presence of the death penalty -in law or practice-does not influence homicide death rates." Not all seem willing to accept this as the "inevitable conclusion," however. Examination of most capital punishment investigations reveals that they suffer from serious theoretical and methodological limitations. In addition, it is highly questionable to assume, as many criminologists have, that results of death penalty investigations may be generalized to noncapital offenses and other forms of punishment.

Recognizing the limitations of death penalty research, a few investigators have examined imprisonment as an alternative form of punishment, and offenses other than homicide. Although the offenses, time periods and punishment variables differ slightly in these investigations, results suggest (1) a substan-

* The Cleveland State University.

** Cuyohoga Community College.

'J. Gibes, Crime, Punishment and Deterrence (1975); Gibbs, Crime, Punishment and Deterrence, 48 SOC. SCIENCE Q. 515 (1968).

${ }^{2}$ Ball, Why Punishment Fails, 31 Am. J. Corr. 19 (1969).

${ }^{3}$ E. Putt kammer, Administration of Criminal Law 11-19 (1953).

'Tittle, Crime Rates and Legal Sanctions, 16 Social Problems 409 (1969).

5T. Sellin, Capital Punishment 138 (1967). tial inverse correlation between certainty of imprisonment and the state's index offense rate, and (2) a less substantial negative correlation (and in some cases a low, positive correlation) between severity of prison sentence and rate variables. ${ }^{6}$

While these investigations have contributed greatly to a better understanding of deterrence, they too are not without limitations. First, these studies have typically made use of notoriously inaccurate police and prisoner statistics in constructing punishment and rate indexes. Second, the punishment measures used rest upon the assumption that the actual punishment practices in a jurisdiction provide a reasonably good indicator of the residents' perceptions of the severity of legal sanctions. Although the evidence is meager, this assumption appears highly questionable. ${ }^{7}$ Likewise, persons may be equally unaware of the proportion of offenses that result in arrest and conviction, that is, the certainty of punishment.

In sum, it would seem highly questionable to assume that the actual punishment practices in a jurisdiction will reflect residents' perceptions of severity, and certainty of punishment. This difficulty imposes a major limitation on most deterrence investigations because deterrence theory suggests that it is one's subjective perceptions of punishment that are important, not the objective probability of apprehension and the actual sanctions that result. It is, therefore, important to examine the relationship between persons' perceptions of punishment and

'Bailey, Gray \& Martin, On Punishment and Crime: Some Methodological Commentary, 19 Social Problems 284 (1971); Bailey, Martin \& Gray, Crime and Deterrence: A Correlation Analysis, $11 \mathrm{~J}$. Res. Crime \& Delinquency 124 (1974); Bailey \& Smith, Punishment: Its Severity and Certainty, 63 J. CRIM. L.C. \& P.S. 530 (1972); Chiricos \& Waldo, Punishment and Crime: An Examination of Some Empirical Evidence, 18 Social Problems 200 (1970); Ehrlich, The Deterrent Effect of Criminal Law Enforcemenl, 1 J. LEgal Issues 259 (1972); Gibbs, Crime, Punishment and Deterrence, 48 Soc. ScIENCE Q. 515 (1968); Tittle, supra note 4. See generally Phillips \& Votey, An Economic Analysis of the Deterrent Effect of Law Enforcement on Criminal Activity, $63 \mathrm{~J}$. CRIM. L.C. \& P.S. 330 (1972).

${ }^{7}$ Cal. Assembly Comm. on Criminal Procedure, Deterrent Effects of Criminal Sanctions (1968). 
their actual criminal involvement. To date, only a few investigations have addressed this question.

\section{Survey Investigations of DeterRence}

In an early study, Rettig and Rawson ${ }^{8}$ examined 136 college students' judgments of the probability that hypothetical persons would steal money under conditions varying in the severity and certainty of punishment. Analysis revealed $\mathrm{E}^{2}$ values of .145 and .032 , respectively, between severity and certainty of anticipated sanctions, and hypothetical theft behavior. Interestingly, severity of expected punishment (public expulsion from college vs. settling the matter privately) proved to be a much better predictor of theft than certainty of punishment (expectation of getting caught).

In a later investigation, Claster attempted "to determine whether different susceptibilities to sanctions can be explained by differences in perceiving the risk of arrest and conviction for criminal behavior." ${ }^{9}$ Comparing a sample of forty-two incarcerated white male delinquents with ninety-five white male non-delinquents, he failed to find a significant difference in the two groups' perceptions of the risk of arrest and conviction for committing murder, burglary, and vehicular homicide. However, of the delinquents and non-delinquents who reported that they might engage in crime under certain conditions (anger, financial necessity, carelessness), delinquents perceived the likelihood of arrest and conviction as less certain.

In a more recent investigation Jensen ${ }^{10}$ examined the relationship between beliefs about the likelihood of experiencing negative sanctions and self-reported delinquency. A large sample of white adolescent males were asked to indicate their extent of agreement with the statement, "people who break the law are almost always caught and punished." 11 Jensen found official $(\gamma=.15)$ and self-reported delinquency $(\gamma=.22)$ to be only moderately associated with this belief.

In the most recent survey investigation of deterrence, Waldo and Chiricos ${ }^{12}$ interviewed a sample of

${ }^{8}$ Rettig \& Rawson, The Risk Hypothesis in Predictive Judgments of Unethical Behavior, $66 \mathrm{~J}$. ABNORMAL \& Social Psychology 243 (1963).

${ }^{9}$ Claster, Comparisons of Risk Perception Between Delinquents and Non-Delinquents, 58 J. CRIM. L.C. \& P.S. 80 (1967).

10 Jensen, "Crime Doesn't Pay" Correlates of a Shared Misunderstanding, 17 Social Problems 189 (1969).

"Id. at 191-92.

${ }^{12}$ Waldo \& Chiricos, Perceived Penal Sanction and Self-Reported Criminality: A Neglected Approach to Deterrence Research, 19 Social. Problems 522 (1972).
321 southern college students. They found a moderate negative association between perceptions of severity of punishment and admitted marijuana use ( $\gamma=$ $-.41, \mathrm{p}<.001$ ), and a very slight correlation between perceived severity and admitted petty theft $(\gamma=-.02)$. In contrast, when perceived likelihood of being caught by the police was related to marijuana use and petty theft, the correlations were more in line with deterrence theory: $\gamma=-.84$ ( $p<$ .001 ), and $\gamma=-.31$ ( $\mathrm{p}<.01$ ), respectively.

Although these investigations suggest that the threat of sanctions may have an important deterrent effect, careful examination shows them to suffer from serious theoretical and methodological limitations. To illustrate, Rettig and Rawson only asked subjects to assess how hypothetical persons, not themselves, might behave under hypothetical circumstances that may influence theft. ${ }^{13}$ Similarly, Waldo and Chiricos did not ask subjects to assess their own chances of being caught if they broke the law, but rather the chances for persons like themselves. ${ }^{14}$ In addition, Claster did not examine the relationship between the subjects' own deviant behavior, and their perceptions of the likelihood of arrest and conviction. Instead, he only reports differences in the perceived probability of sanctions between delinquents and non-delinquents who admit the possibility of hypothetical deviant behavior.

Furthermore, in the investigations that attempt to relate directly subjects' own deviance with their perceptions, indices of certainty and severity of punishment are quite crude. Jensen, for example, compared the students' delinquency with their responses to this statement: "Persons who break the law are almost always caught and punished." 15

${ }^{13}$ Rettig \& Rawson, supra note 8, at 244, asked subjects to estimate expectancy of censure (certainty of punishment) on a six-point scale (0-6), with six indicating that "the student expects to get caught," and zero indicating that the "student does not expect to get caught." Reinforcement value of censure (severity of punishment) was also measured on a six-point scale, with high severity operationalized as "the student will be publicly expelled from the university" and low severity as "the student will be able to settle the matter privately."

${ }^{14}$ Waldo \& Chiricos, supra note 12 , measured perceived certainty of punishment for marijuana use and petty theft by responses to the questions: (1) "If someone like yourself used marijuana occasionally in Tallahassee (Florida), how likely are the police to catch him (her)?," and (2) "If someone like yourself stole something worth less than $\$ 100$ in Tallahassee, how likely are the police to catch him (her)?"

${ }^{15} \mathrm{Jensen}$ 's subjects were asked to respond to this question using a five-point Likert format ranging from strongly agree (high perceived certainty) to strongly disagree (low perceived certainty). As Jensen points out, these data only 
Similarly, Waldo and Chiricos measured perceived severity by asking: "If you were convicted of crime, how likely would you be to get the maximum Florida penalty?" ${ }^{16}$ In sum, while these investigations provide an important contribution to the literature, their shortcomings clearly point to the need for additional research in this area. ${ }^{17}$

\section{The Present Investigation}

To avoid some of these difficulties we examine here: (1) subjects' perceptions of their own likelihood of arrest and conviction if they were to violate the law, (2) subjects' perceptions of the severity of official and unofficial sanctions that would result if they were to violate the law, and (3) the relationship between subjects' perceptions of severity and certainty and their own extent of criminal involvement. In addition, four personality variables believed to influence perceptions and offense behavior are considered. Two general hypotheses are examined: (1) there is a substantial inverse relationship between perceptions of the certainty of punishment and extent of criminal involvement; and (2) there is a substantial inverse relationship between perceptions of the severity of punishment and extent of criminal involvement.

\section{METHODOLOGY}

To examine these hypotheses a questionnaire was administered to 268 sophomore, junior, and senior level students enrolled in sociology courses at an urban midwestern university. Selection of subjects was restricted to exclude freshman in order to ensure

provide a very general indicator of certainty for: (1) no distinction is allowed for the relative riskiness of different offenses, and (2) no distinction is made "between the apprehension process and the sanctioning process since the questionnaire item asked for their belief regarding the chances of being caught and punished." Jensen, supra note 10 , at 192 .

${ }^{16}$ Waldo \& Chiricos, supra note 12 , measured perceived severity of punishment for marijuana use and petty theft by responses to the question: (1) "If you were convicted of possession of marijuana, how likely would you be to get the maximum Florida penalty?," and (2) "If you were convicted of stealing something worth less than $\$ 100$, how likely would you be to get the maximum Florida penalty?"

${ }^{17}$ Tittle \& Logan argue that "at this point we can safely say only that sanctions apparently have some deterrent effect under some circumstances." Consequently, there is now a need for "more careful research in an attempt to specify the conditions under which sanctions are likely to be important influences on behavior." Tittle \& Logan, Sanctions and Deviance; Evidence and Remaining Questions, 7 Law \& Soc'y Rev. 371 (1973). See F. Zimring \& G. Hawkins, Deterrence: The Legal Threat in Crime Control (1973).
TABLE I

Subjects' Perceptions of Their OWN Likelihood of Arrest and Conviction Compared to "Persons Like Themselves"*

\begin{tabular}{|c|c|c|c|c|}
\hline \multirow[t]{2}{*}{ Response } & \multicolumn{2}{|c|}{$\begin{array}{c}\text { Perceived } \\
\text { Likelihood of } \\
\text { Arrest }\end{array}$} & \multicolumn{2}{|c|}{$\begin{array}{l}\text { Perceived } \\
\text { Likelihood of } \\
\text { Conviction }\end{array}$} \\
\hline & No. & Per Cent & No. & Per Cent \\
\hline Much more likely & 24 & 9.0 & 26 & 9.8 \\
\hline More likely & 54 & 20.3 & 67 & 25.2 \\
\hline Equally as likely & 149 & 56.0 & 133 & 50.0 \\
\hline Less likely & 23 & 8.6 & 28 & 10.5 \\
\hline Much less likely & 16 & 6.0 & 12 & 4.5 \\
\hline
\end{tabular}

* Data were obtained from responses to the questions: "Compared to other persons like yourself, how likely do you think it would be that you would be arrested if you committed a crime?" and "Compared to other persons like yourself, how likely do you think it would be that you would be convicted in court if you committed a crime?"

that only persons at least nineteen years of age, and thus subject to legal sanctions as adults for at least one year, would be included in the sample. ${ }^{18}$ Of the 268 students surveyed, 266 questionnaires $(99.3$ per cent) could be used, with only two students refusing to cooperate in the investigation.

\section{Certainty of Punishment}

Unlike previous investigations, subjects were asked to estimate their own chances of apprehension and conviction if they were to violate the law rather than those of a "generalized other" or "someone like themselves" (see appendix, questions 1 and 2). ${ }^{19}$ A pretest revealed that many persons see their own chances of arrest and conviction as quite different from persons otherwise like themselves. To put this question to a systematic test, subjects were asked to compare their chances of arrest and conviction if they broke the law with "other persons like themselves" (see appendix, questions 3 and 4). Results are summarized in Table I. These data indicate that roughly half of the subjects see themselves as either

${ }^{18}$ Although an attempt was made to survey all students enrolled in these classes, this was not possible in one case where all but five students had been previously contacted in another class. In addition, on the days the survey was conducted, there was an estimated absentee rate of four to eight percent.

${ }^{19}$ Also unlike previous investigations, subjects were asked to estimate their chances of arrest and conviction in percentage terms. Allowing them to express their perceptions in these terms ( $0-100$ per cent certainty) would clearly seem preferable to the rather crude certainty measures used by Waldo \& Chiricos, Jensen, and Rettig \& Rawson. 
more or less likely to be arrested and convicted than "persons like themselves." It would, therefore, seem methodologically more sound to focus upon self-perceptions in examining criminal involvement than to use measures like those found in previous investigations.

\section{Severity of Punishment}

Subjects' perceptions of the severity of sanctions were measured by asking them to anticipate: (1) what would happen if they were caught by the police commiting each of five offenses (see appendix, question 5), and (2) the reaction they would expect from parents and friends if they were caught committing each offense (see appendix, questions 6 and 7). These questions allow an examination of both the official and unofficial sanctions subjects would anticipate. Deterrence investigations of the latter class of sanctions are completely absent from the literature.

\section{Criminal Involvement}

After completing the "perceptions" section of the questionnaire, subjects were asked to indicate, by way of a brief, anonymous inventory, the extent of their involvement over the last twelve months in: use of marijuana, sale of marijuana, petty theft, grand theft and shoplifting. A limited one year time period was chosen here to minimize distortion in reporting due to problems of memory, and because we are concerned with the relationship between current perceptions and recent criminal activity. Distant offense behavior may or may not reflect current perceptions of punishment. ${ }^{20}$

\section{Personality Factors}

Zimring, ${ }^{21}$ and Zimring and Hawkins ${ }^{22}$ mention the following "personality types" as least subject to

${ }^{20}$ The questionnaire used consisted of three major sections. Subjects were first asked to respond to the perceptions questions, next to complete a brief self-report inventory, and finally to respond to the CPI personality items. After completing each section of the questionnaire, they were asked to stop and await further instructions. In addition, students were instructed not to refer back to earlier sections of the questionnaire in responding to items.

While it would have been of interest to vary the ordering of the three sections of the questionnaire for different groups of subjects to see if the ordering used influenced responses, we unfortunately failed to take this consideration into account.

${ }^{21} \mathrm{~F}$. Zimring, Perspectives on Deterrence (1971 Public Health Service Publication No. 2056).

${ }^{22}$ F. Zimring \& G. Hawkins, Deterrence: The Legal Threat in Crime Control (1973). the threat of sanctions and deterrence: (1) present vs. future oriented, (2) optimists vs. pessimists, (3) impulsive vs. careful planners, (4) aggressive vs. passive, (5) individualists vs. other-directed and (6) non-authoritarians vs. authoritarians. In addition, criminologists have long argued that the effect of punishment may be dependent upon one's attachment to sources of informal social control, stake in conformity (what one has to lose), sense of conscience (socialization strength), and self-assessment as a responsible, law-abiding person. ${ }^{23}$ To examine some of these notions, subjects were administered four subscales of the California Psychological Inventory (CPI) that most closely correspond to the above factors: Responsibility (Re), Socialization (So), SelfControl (Sc), and Achievement via Conformity (Ac). A brief description of each CPI subscale is presented in Table II.

Following Zimring and Hawkin's argument ${ }^{24}$ and Gough's ${ }^{25}$ suggestions for interpreting the CPI, we hypothesized: (1) a substantial negative correlation between each personality factor and subjects' extent of criminal involvement, and (2) an improvement in predicting criminal involvement by considering both personality factors and perceptions of punishment instead of considering either separately.

\section{Data Processing and Analysis}

The measures of association used to examine the above hypotheses are Pearson Product Moment Correlation ( $r$ and $R$ ) and point biserial correlation $\left(r_{p b}, R_{p b}\right)$. Product Moment correlation is used to measure the bivariate and multiple associations between certainty of punishment and offense behavior, and personality and offense behavior. The assumption of interval level of measurement required by this measure would appear to be met for these variables. Point biserial correlation was chosen to examine the bivariate and multiple association between severity of punishment and offense behavior, for the severity index only forms an ordinal contin-

${ }^{23}$ R. Caldwell, Criminology (1965); F. Zimring, supre note $21 ; \mathrm{F}$. Zimring \& G. HAw KINS, supra note 22; Andenaes, General Prevention-Illusion or Reality, $43 \mathrm{~J}$. CRIM. L.C. \& P.S. 176 (1952); Ball, The Deterrence Concept in Criminology and Law, $46 \mathrm{~J}$. CRIM. L.C. \& P.S. 347 (1955); Jeffrey, Criminal Behavior and Learning Theory, 56 J. CRIM. L.C. \& P.S. 294 (1965); Schmideberg, The Offender's Attitude Toward Punishment, 51 J. CRIM. L.C. \& P.S. 328 (1961). See generally ConTEMPorary Corrections (P. Tappan ed. 1951).

${ }^{24} \mathrm{~F}$. ZimRING \& G. Hawkins, supra note 22.

${ }^{25} \mathrm{H}$. Gough, Manual for the California PsyCHOLOGICAL INVENTORY (1957). 
TABLE II

Seleected Subscales and Purposes from the Galifornia Psychological Inventory

Characteristics of

High Scorers
Characteristics of

Low Scorers
Responsibility (Re): To identify persons of conscientious, responsible and dependable disposition and temperament.

Socialization (So): To indicate the degree of social maturity, integrity and rectitude which the individual has attained.

Self-Control (Sc): To assess the degree and adequacy of self-regulation, freedom from impulsivity and selfcenteredness.

Achievement via Conformance (Ac): To identify those factors of motivation which facilitate achievement where conformance is positive.
Planful, responsible, independent, conscientious, dependable, resourceful, efficient, alert to ethical and moral issues.

Serious, honest, industrious, obliging, sincere, responsible, self-denying, conforming.

Calm, patient, practical, self-denying, inhibited, thoughtful, deliberate, strict, thorough in their own work, honest.

Co-operative, efficient, organized, responsible, sincere, industrious, valuing intellectual achievement.
Immature, moody, awkward, disbelieving, influenced by personal bias, spiteful, impulsive.

Defensive, demanding, opinionated, resentful, stubborn, undependable, deceitful, given to excess exhibition.

Impulsive, shrewd, excitable, selfcentered, uninhibited, aggressive, assertive.

Coarse, stubborn, aloof, awkward, insecure, opinionated, easily disorganized under stress, pessimistic.

Source: H. Gough, Manual for the California Psychological Inventory 10-11 (1957).

uum from least to most severe response by police, family, and friends. ${ }^{26}$

${ }^{26}$ While an ordinal level measure like Goodman and Kruskal's gamma or Somer's dyx might have been used here, it was decided against for three reasons. First, the underlying prediction rules and interpretation of these ordinal measures and Pearson's $r$ are quite different making it difficult to compare results for different independent variables. In contrast, product moment $r$ and point biserial $r$ have the same underlying prediction rule and may be given the same interpretation. Second, to reduce level of measurement for the certainty of punishment, personality and offense variables, and conduct an ordinal contingency analysis $(2 \times 2,3 \times 3$, etc. $)$ would result in an important loss in the precision of the data: Third, to examine, the combined effects of severity, certainty and personality on offense behavior, a multiple measure of association is required. Unfortunately, no well developed multiple correlation technique is available for ordinal data that would allow an examination of the effects of three independent variables, with a total of nine sub-diminensions (two for certainty, three for severity and four for personality).

In using point biserial correlation, weights of zero (0) were assigned perceived severity of response by: (1) police, with less than conviction resulting, (2) parents, with a neutral or positive response, and (3) friends, with a neutral or positive response. Weights of one (1) were assigned perceived severity of response by: (1) police, when apprehension would lead to conviction and some form of sentence, (2) parents who would be at least displeased, and (3) friends who would be at least displeased. For a discussion of point biserial correlation and the use of "dummy variables" with assigned values of zero and one in bivariate and multivariate analyses see P. Blau \& O. Duncan, The American
Conventional tests of statistical significance are not used in this analysis because important assumptions required by these tests, most notably independent random sampling, cannot be met. Consequently, we have arbitrarily chosen to regard as "large" those coefficients which exceed .500 , and as "moderate" those coefficients between .400 and .500 . Correlations below .400 are considered as "low."

\section{Findings}

\section{Certainty of Punishment}

Table III reports the association between subjects' perceptions of their likelihood of arrest and conviction if they were to violate the law, and their self-reported criminal involvement. These figures reveal a picture generally inconsistent with our first hypothesis. While the correlations between likelihood of arrest and self-reported use of marijuana,

Occupational Structure (1967); D. Morgan \& B. Choen, Income and Welfare in the United States (1962); Gujarati, Use of Dummy Variables in Testing for Equality Between Sets of Coefficients in Linear Regressions: A Generalization, 24 AM. STAт. 18 (Dec. 1970); Gujarati, Use of Dummy Variables in Testing for Equality Between Sets of Coefficients in Two Linear Regressions: A Note, 24 Am. STat. 50 (Feb. 1970); Suits, Use of Dummy Variables in Regression Equations, $52 \mathrm{~J}$. Am. Statistical Ass'n 548 (1957); 'Treiman, Status, Discrepancy and Prejudice, 71 AM. J. Sociology 651 (1966). 
TABLE III

Correlations Between Perceived Certainty of Punishment and Criminal Involvement for OfFENSES*

\begin{tabular}{lcc}
\hline \multicolumn{1}{c}{ Offense } & $\begin{array}{c}\text { Perceived } \\
\text { Probability } \\
\text { of Arrest }^{\mathrm{a}}\end{array}$ & $\begin{array}{c}\text { Perceived } \\
\text { Probability of } \\
\text { Conviction }^{\mathrm{b}}\end{array}$ \\
\hline Marijuana Use & -.094 & .039 \\
$\begin{array}{l}\text { Sale of Marijuana } \\
\text { Petty Theft (stealing some- } \\
\quad \text { thing worth under } \$ 60)\end{array}$ & -.072 & -.040 \\
$\begin{array}{l}\text { Grand Theft (stealing some- } \\
\quad \text { thing worth over \$60) }\end{array}$ & -.019 & -.072 \\
\begin{tabular}{l} 
Shoplifting \\
\hline
\end{tabular} & -.044 & -.162 \\
\hline
\end{tabular}

* Coefficients are Pearson Product Moment Correlations.

a See question 1 in appendix.

${ }^{b}$ See question 2 in appendix.

sale of marijuana and grand theft are in the predicted negative direction, none may be considered very substantial. Also, contrary to our expectations, the correlations are positive, but low, for petty theft and shoplifting.

When certainty is operationalized as likelihood of conviction, a similar picture results. Here the correlations for sale of marijuana, petty theft and grand theft are in the predicted negative direction; but again, they are quite low. Like perceptions of arrest, correlations for marijuana use and shoplifting are positive and low.

While these findings are contrary to what deterrence theory would predict, they are not out of line with previous investigations. Rettig and Rawson ${ }^{27}$ found only a slight inverse relationship $\left(\mathrm{E}^{2}=.032\right)$ between hypothetical theft behavior and certainty of detection. Similarly Jensen ${ }^{28}$ reports low-moderate correlations between adolescents' perceptions of certainty and official $(\gamma=.15)$ and self-reported delinquency involvement $(\gamma=.22)$.

In contrast, Waldo and Chiricos ${ }^{29}$ report very significant correlations between perceived likelihood of arrest and self-reported marijuana use $(\gamma=$ $.84, \mathrm{P}<.001)$ and petty theft $(\gamma=.31, \mathrm{P}<.01)$. The reason for the difference between their findings, and ours and those of other investigators, may lie in Waldo and Chiricos' methodology. First, they did not ask subjects to estimate their own changes of arrest for marijuana use and petty theft. Rather, they asked subjects to estimate chances of arrest for "someone like themselves." Second, Waldo and

\footnotetext{
${ }^{27}$ Rettig \& Rawson, supra note 8.

${ }^{28}$ Jensen, supra note 10 .

${ }^{29}$ Waldo \& Chiricos, supra note 12.
}

TABLE IV

Correlations Between Perceived Severity of Punishient and Criminal Inyolvement for Selected OFFENSES*

\begin{tabular}{|c|c|c|c|}
\hline Offense & $\begin{array}{c}\text { Police } \\
\text { Reaction }\end{array}$ & $\begin{array}{l}\text { Parents' } \\
\text { Reaction }\end{array}$ & $\begin{array}{l}\text { Friends' } \\
\text { Reaction }\end{array}$ \\
\hline Marijuana Use & .023 & -.159 & -.141 \\
\hline Sale of Marijuana & -.001 & -.031 & -.176 \\
\hline $\begin{array}{l}\text { Petty Theft } \text { (stealing } \\
\text { something } \\
\text { worth } \\
\text { under } \$ 60 \text { ) }\end{array}$ & -.158 & .103 & .070 \\
\hline $\begin{array}{l}\text { Grand Theft (stealing } \\
\text { something worth over }\end{array}$ & & & \\
\hline$\$ 60)$ & -.003 & 167 & 036 \\
\hline Shoplifting & -.035 & .005 & .012 \\
\hline
\end{tabular}

* Coefficients are point biserial correlations.

${ }^{a}$ See question 5 in appendix.

${ }^{-}$See question 6 in appendix.

'See question 7 in appendix.

Chiricos did not ask subjects to estimate the likelihood of arrest if they were to violate the law, i.e., use marijuana. Rather, they asked them to estimate chances of arrest if they used "marijuana occasionally." As a result, their findings may tell us little about perceptions for other types of use. Third, Waldo and Chiricos asked subjects to express their chances of arrest as either "likely," " $50 / 50$," or "unlikely," while we asked subjects to express their perceptions on a more realistic scale ranging from 0 to 100 per cent. Similarly, they dichotomized subjects into those never having committed an offense (nonoffenders) and those having committed an offense one or more times (offenders), while we examined the association between the actual number of self-reported offenses and perceptions of arrest and conviction.

\section{Severity of Punishment}

Table IV reports the association between subjects' perceptions of the severity of unofficial and official sanctions and reported involvement in five offenses. Like certainty, these data also reflect a picture generally contrary to our hypothesis. For four offenses, the correlations are in the predicted negative direction; the coefficients are all quite low, however. For marijuana use the correlation is positive.

When perceived severity of unofficial sanctions is examined, the correlations are only negative for the two marijuana offenses. Again, however, the coefficients are quite low. For petty theft, grand theft and shoplifting, the correlations are positive and low.

These findings, while inconsistent with our hy- 
TABLE V

Correlations Between Perceived Severity of Punishment and Criminal Involvement Controlling for Level of Perceived Certainty*

\begin{tabular}{llrrr}
\hline Offense & $\begin{array}{c}\text { Perceived } \\
\text { Level of } \\
\text { Certainty }\end{array}$ & $\begin{array}{c}\text { Severity of } \\
\text { Police } \\
\text { Reaction }\end{array}$ & $\begin{array}{r}\text { Severity of } \\
\text { Parents' } \\
\text { Reaction }\end{array}$ & $\begin{array}{r}\text { Sevcrity of } \\
\text { Friends' } \\
\text { Reaction }\end{array}$ \\
\hline Marijuana Use & Low & .015 & .103 & .206 \\
& Moderate & .031 & .150 & .316 \\
Sale of Marijuana & High & -.026 & .016 & .050 \\
& Low & -.058 & -.025 & .219 \\
& Moderate & .028 & .152 & .042 \\
Petty Theft (stealing something worth under \$60) & High & .031 & -.035 & .190 \\
& Low & -.192 & -.089 & -.062 \\
& Moderate & .029 & .151 & -.072 \\
Grand Theft (stealing something worth over \$60) & High & -.122 & .008 & .025 \\
& Low & .061 & -.125 & -.069 \\
& Moderate & .066 & .126 & .119 \\
Shoplifting & High & -.178 & -.132 & -.187 \\
& Low & .018 & -.090 & -.026 \\
& Moderate & -.188 & -.088 & -.027 \\
& High & -.018 & -.083 & .100 \\
\hline
\end{tabular}

* Coefficients are point biserial correlations.

potheses, are also generally in line with previous investigations. Rettig and Rawson ${ }^{30}$ found a lowmoderate correlation $\left(\mathrm{E}^{2}=.155\right)$ between hypothetical theft behavior and perceived severity of sanctions. Similarly, Waldo and Chiricos ${ }^{31}$ report a moderate correlation $(\gamma=-.41)$ between self-reported marijuana use and perceived severity, and a near zero correlation $(\gamma=-.02)$ between severity and petty theft.

While our findings are quite similar to Waldo and Chiricos' for petty theft, their more substantial correlation for marijuana use may again reflect the methodological differences between our investigations. As noted, they measured perceived severity by asking: "If you were convicted of possession of marijuana, how likely would you to be to get the maximum Florida penalty?" In contrast, we permitted subjects more flexibility in response by asking them to anticipate the type of reaction they would expect if caught by the police: release, arrest, conviction, etc.

\section{Severity vs. Certainty of Punishment}

In examining the deterrence literature, one repeatedly finds the assertion that the certainty of punishment is a more effective deterrent than its severity. ${ }^{32}$

${ }^{\text {so }}$ Rettig \& Rawson, supra note 8.

31 Waldo \& Chiricos, supra note 12.

${ }^{32}$ E. Putt Kammer, supra note 3; Andenaes, supra note 23; Jeffrey, supra note 23; Tittle \& Logan, Sanctions and Deviance: Evidence and Remaining Questions, 7 LAw \& Soc'y REv. 371 (1973).
While the evidence is clearly suggestive of certainty's greater deterrent value, some caution should be exercised in drawing any firm conclusion at this time. Both classic ${ }^{33}$ and more recent theoretical discussions of deterrence ${ }^{34}$ point out that punishment and its severity do not operate in a vacuum. The deterrent value of punishment, no matter how severe, is dependent upon its certainty. Accordingly, the important question concerning punishment's severity would appear to be, how is the relationship between severity and offense behavior influenced by level of certainty? To examine this question correlations were computed between a subject's perceptions of severity and reported offense behavior, controlling for perceived level of certainty. Results are reported in Table $\mathrm{V}$.

In line with deterrence theory, we would predict that the higher the level of certainty (chance of arrest by the police), the more substantial the inverse relationship between severity and offense behavior. Table $V$ reveals no single offense where the coefficients are all in the predicted negative direction between severity of police reaction and self-reported deviance. Partially in line with our prediction, however, are the findings for marijuana use and

${ }^{33}$ C. Beccaria, Essays on Crime and Punishment (1918); J. Bentham, Principles of Penal Law (1843); E. Ross, Social Control (1901).

${ }^{34} \mathrm{~J}$. GibBs, supra note 1; F. ZimRIng \& G. Hawkins, supra note 22; F. ZimRING, supra note 21 ; Andenaes, supra note 23. 
grand theft. For these two offenses the correlations are negative for those subjects perceiving high certainty, and positive for those perceiving the chance of apprehension as low. For sale of marijuana, the only negative correlation is for those subjects seeing certainty as low.

The relationship between perceived severity of unofficial sanctions (parents and friends) and reported criminal involvement, controlling for certainty, also reveals a picture generally inconsistent with deterrence. Only for shoplifting and for one source of sanctions, parents, are the correlations in the predicted direction. The near identical size of the coefficients, however, suggests that the perceived chance of apprehension does not effect the severityoffense relationship for this offense.

While falling outside of the predicted pattern, correlations for grand theft (parents and friends) may be interpreted as at least partially in line with deterrence. For these offences the negative correlations are slightly larger for those subjects seeing apprehension by the police as high, compared to those seeing certainty as low. In each case, however, the coefficients are positive for those viewing chances of apprehension as moderate.

Also partially in line with deterrence, the largest positive correlations between severity and marijuana use and sale of marijuana (friends only) hold for those subjects viewing the chance of being caught by the police as low or moderate. The lowest positive correlations hold for those perceiving certainty as high. For petty theft and shoplifting (friends only), however, this pattern is reversed with correlations being positive for those who see the chance of apprehension as high, and negative for those seeing certainty as low. In sum, these data provide little support for the notion that the deterrent effect of severity of punishment is dependent upon its certainty. ${ }^{35}$

\section{Personality and Criminal Involvement}

In line with Gough's interpretation of the CPI, we would expect a substantial negative correlation between each personality subscale score and criminal involvement, i.e., those most responsible, most socialized, having the greatest self-control and most oriented toward achievement via conformity should be least involved in crime. Table VI reveals a picture

\footnotetext{
${ }^{35}$ The relationship between severity of punishment and offense behavior was also found to be contrary to our hypothesis and deterrence theory when the perceived chance of conviction in court was introduced as a measure of certainty.
}

only partially consistent with Gough's argument. As predicted, correlations are negative for responsibility and self-control for all five offenses. The coefficients are all low, however. For the remaining two subscales a "mixed pattern" results. For socialization, the correlations are negative for petty theft and grand theft but positive for shoplifting and use and sale of marijuana. For achievement via conformity, the pattern is reversed with positive correlations for petty and grand theft and negative correlations for use and sale of marijuana and shoplifting. In sum, while the dominant pattern in Table VI is a negative relationship between personality and crime ( 80 per cent of the correlations are negative), all of the coefficients are quite low with the largest, between socialization and sale of marijuana $(r=.251)$, being positive. While these findings are generally inconsistent with what Gough and others would lead us to expect, they are not totally out of line with previous investigations of personality and crime.

In an early investigation by Schuessler and Cressey $^{36}$ a review of 113 studies revealed fortyseven cases ( 42 per cent) where offenders and nonoffenders were successfully differentiated by various personality inventories. The tests that seemed to best differentiate criminals from non-criminals, however, did not consistently discriminate between these two from investigation to investigation, nor did repetition of the tests yield the same results. These findings and the serious methodological difficulties involved in most of these investigations led Schuessler and Cressey to conclude that, as often as not, "personality traits are distributed in the criminal population in about the same way as in the general population." 37

In contrast, a more recent survey of the literature (1950-1965) on personality characteristics of criminals by Waldo and Dinitz ${ }^{38}$ reports that the majority of studies $(76 / 94=81$ per cent) reviewed showed significant differences between offenders and nonoffenders. They too, however, found that many of the studies examined suffered from serious methodological shortcomings, thus questioning the theoretical significance of their findings. They conclude that "the results of this review indicate that 'personality' cannot be dismissed readily, as it is by many sociologists, and its etiologic role cannot be assumed

\footnotetext{
${ }^{36}$ Schuessler \& Cressey, Personality Characteristics of Criminals, 55 AM J. Sociology 476 (1950).

${ }^{37} I d$. at 483.

${ }^{38}$ Waldo \& Dinitz, Personality Attributes of the Crimtnal: An Analysis of Research Studies, 4 J. Res. Crime \& Delin QuenCY 185 (1967).
} 
TABLE VI

Correlations Between Subscale Scores of the California Psychológical Inventóry and Griminal INVOLVEMENT For SELECTED OFFenses*

\begin{tabular}{lcccc}
\hline \multirow{2}{*}{ Offense } & \multicolumn{4}{c}{ CPI Subscales } \\
\cline { 2 - 5 } & Responsibility & Socialization & Self-Control & $\begin{array}{c}\text { Achievement } \\
\text { via Conformity }\end{array}$ \\
\hline Marijuana Use & -.120 & .121 & -.021 & -.067 \\
Sale of Marijuana & -.044 & .251 & -.027 & -.052 \\
Petty Theft (stealing something worth under $\$ 60)$ & -.046 & -.017 & -.192 & .074 \\
Grand Theft (stealing something worth over $\$ 60)$ & -.047 & -.030 & -.188 & .036 \\
Shoplifting & -.041 & .130 & -.018 & -.032 \\
\hline
\end{tabular}

* Coefficients are Pearson Product Moment Correlations.

TABLE VII

Multiple Correlations Between Offense Behavior and Perceptions of the Severity and Certainty of Punishment, Subscale Scores of the CPI, and Perceptions and the CPI Combined*

\begin{tabular}{|c|c|c|c|c|c|c|c|c|}
\hline \multirow{3}{*}{ Offense } & \multicolumn{2}{|c|}{ Col. 1} & \multicolumn{2}{|c|}{ Col. 2} & \multicolumn{2}{|c|}{ Col. 3} & Col. 4 & Col. 5 \\
\hline & \multicolumn{2}{|c|}{$\begin{array}{l}\text { Perceptions of } \\
\text { Punishment }\end{array}$} & \multicolumn{2}{|c|}{$\begin{array}{l}\text { CPI Subscales } \\
\text { (Re, So, Sc, Ac) }\end{array}$} & \multicolumn{2}{|c|}{$\begin{array}{l}\text { Perceptions of } \\
\text { Punishment and } \\
\text { CPI Combined }\end{array}$} & \multicolumn{2}{|c|}{$\begin{array}{l}\text { Per Cent of } \\
\text { Ind. Exp. } \\
\text { Var. Accounted } \\
\text { for by }\end{array}$} \\
\hline & $\mathbf{R}$ & $\mathrm{R}^{2}$ & $\mathbf{R}$ & $R^{2}$ & $\mathbf{R}$ & $\mathrm{R}^{2}$ & $\begin{array}{l}\text { Percep- } \\
\text { tions }\end{array}$ & $\mathrm{CPI}^{* * *}$ \\
\hline Marijuana Use & .227 & .052 & .184 & .034 & .291 & .085 & 5.1 & 3.3 \\
\hline Sale of Marijuana & .191 & .036 & .267 & .071 & .316 & .100 & 2.9 & 6.4 \\
\hline \multicolumn{9}{|c|}{ Petty Theft (stealing something worth under } \\
\hline$\$ 60)$ & .214 & .046 & .212 & .045 & .297 & .088 & 4.3 & 4.2 \\
\hline \multicolumn{9}{|c|}{ Grand Theft (stealing something worth over } \\
\hline$\$ 60)$ & .243 & .059 & .199 & .040 & .305 & .093 & 5.3 & 4.0 \\
\hline Shoplifting & .096 & .009 & .144 & .021 & .171 & .029 & .8 & $2.0^{\circ}$ \\
\hline
\end{tabular}

* Coefficients are Pearson Product Moment Correlations.

** Column 4 equals Column 3 minus Column 2.

*** Column 5 equals Column 3 minus Column 1.

casually, as it is by many psychiatrists and psychologists." 39

\section{Perceptions, Personality and Criminal Involvemen't}

While neither perceptions of punishment nor personality proves to be a good predictor of selfreported behavior, it might be of interest to examine their combined effect on our dependent variable. To examine this question each dimension of certainty (police apprehension, conviction in court), severity (police, parents' and friends' reactions) and personality ( $\mathrm{Re}, \mathrm{So}, \mathrm{Sc}, \mathrm{Ac}$ ) were fit into a multiple correlation analysis. Results are reported in Table VII.

Figures in columns 1 and 2 show a generally weak

${ }^{39} 1 d$. at 202 . association between offense behavior and the combined effects of perceptions of punishment and personality, respectively. The largest multiple coefficient for perceptions $\left(R=.243, R^{2}=.059\right)$ permits less than six percent explained variation in grand theft, while the largest multiple correlation for personality $\left(\mathrm{R}=.267, \mathrm{R}^{2}=.071\right.$ ) permits only about seven percent explained variation in sale of marijuana.

The combined effects of perceptions and personality are reported in column 3 . Comparison of these figures with those in columns 1 and 2 reveals a slight improvement in predicting reported offense behavior by considering both perceptions and personality over either variable separately. The multiple correlations are all quite low, however.

Column 4 and 5 of Table VII report the percent- 
age of independently explained variation in reported offense behavior permitted by perceptions and personality, respectively. Comparison of these figures with the respective $R^{2}$ values in columns 1 and 2 shows them to be nearly identical in size (with slight rounding error), thus indicating very little common variation explained by perceptions and personality. A similar pattern holds for the remaining offenses. Further, when $\mathrm{R}^{2}$ values for perceptions (column 1) and personality (column 2) are added together, they roughly equal, with slight rounding error, the $\mathrm{R}^{2}$ values when the effects of perceptions and personality are combined (column 3 ). This indicates negligible statistical interaction between personality and perceptions. In sum, contrary to Zimring's and Zimring and Hawkins' ${ }^{40}$ assertion, perceptions of punishment and personality appear to be generally unrelated as they affect offense behavior.

\section{Summary and Conclusion}

To briefly summarize our findings: First, perceptions of certainty and severity of punishment proved generally unrelated to reported criminal involvement in each offense. For each dimension of punishment (Tables III and IV) the dominant pattern is a very slight negative, or slight positive, correlation between these variables.

Second, the relationship between perceived severity of both official and unofficial sanctions and reported behavior, was found to be generally unaffected by perceived certainty of apprehension by the police (Table V).

Third, each of the four personality factors from the CPI was found to be generally unrelated to reported involvement in any offense. While the dominant pattern is a negative correlation between each personality variable and offense behavior, the coefficients are all quite low (Table VI).

${ }^{10} \mathrm{~F}$. Zimring, supra note 21 ; F. Zimrino \& $\mathrm{G}$. Hawkins, supra note 22.
Fourth, comparison of findings for perceptions with those for personality shows each to have an independent, but negligible, effect on reported offense behavior, with no more than 1 per cent common variance accounted for in any offense by these two factors (Table VII).

Finally, by considering both perceptions and personality together, only a slight improvement results in explaining admitted offense behavior over considering each of these variables separately. For no single offense, do these two factors, with a total of nine subdimensions, allow more than a 10 per cent explained variation in the dependent variable. In sum, contrary to deterrence theory and our hypotheses, perceptions of punishment and personality, as measured here, do not appear to be important determinants of criminal involvement.

\section{The Present Investigation And Further Research}

Despite our attempts to build upon the shortcomings of previous survey investigations, the present study suffers from some limitations that should be briefly noted. First, only two dimensions of punishment, its certainty and severity, have been examined. The swiftness of the punishment was not considered. Second, only five offenses were examined; many other offenses remain to be considered as well. Third, only two sources of unofficial sanctions were examined. Reactions of school officials, employers, the church, neighbors, etc., should be considered. Fourth, our analysis was confined to a sample of upper-division college students, with many other populations in need of examination. Finally, only four personality factors from one psychological inventory were examined; other personality variables and inventories must be considered as well. In short, while we have attempted to meet a number of shortcomings found in previous analyses, a number of questions remain to be examined.

\section{APPENDIX}

\section{QUESTIONNAIRE ITEMS}

1. If you were to commit each of the crimes listed below, what do you think your chances would be of getting caught by the police?

2. If you were to commit each of the crimes below, what do you think your chances would be of getting caught and convicted in court?

3. Compared to "other persons like yourself," how likely do you think it would be that you would be arrested if you committed a crime?

4. Compared to "other persons like yourself," how likely do you think it would be that you would be convicted in court if you committed a crime? 
5. What do you think would happen to you if you were caught by the police committing the following crimes?

1. release by the police without arrest

2. arrest but no conviction

3. conviction with probation and/or a fine only

4. conviction and a jail sentence

5. conviction and a prison sentence

6. If your parents (guardian) found out that you had committed the crimes listed below, how do you think they would feel about you?

1. very displeased

2. displeased

3. neutral-no feelings one way or the other

4. pleased

5. very pleased

7. If your close friends found out that you had committed the crimes listed below, how do you think they would feel about you?

1. very displeased

2. displeased

3. neutral-no feelings one way or the other

4. pleased

5. very pleased 